Mar. Drugs 2004, 2, 170-175

Marine Drugs

ISSN 1660-3397

www.mdpi.net/marinedrugs/

\title{
Parguerol and Isoparguerol Isolated from the Sea Hare, Aplysia kurodai, Induce Neurite Outgrowth in PC-12 Cells
}

\author{
Sachiko Tsukamoto,* Yuko Yamashita, Takushi Yoshida, and Tomihisa Ohta \\ Faculty of Pharmaceutical Sciences, Kanazawa University, Kakuma-machi, Kanazawa 920-1192, \\ Japan \\ * Author to whom correspondence should be addressed; Tel. +81-76-234-4469, Fax \\ +81-76-264-6241, E-mail: sachiko@p.kanazawa-u.ac.jp
}

Received: 21 August 2004 / Accepted: 10 October 2004 / Published: 25 November 2004

\begin{abstract}
The extract of the sea hare, Aplysia kurodai, showed neurotrophic activity toward rat pheochromocytoma (PC-12) cells. Bioassay-guided purification afforded two active compounds, which were subsequently identified to be parguerol and isoparguerol by spectroscopic analysis. It was found that both parguerol and isoparguerol induced neurite outgrowth in PC-12 cells at concentrations of 25 and $50 \mu \mathrm{M}$, respectively.
\end{abstract}

Keywords: neurotrophic, parguerol, isoparguerol, sea hare.

\section{Introduction}

It is well known that neurons are terminally differentiated cells. Neurotrophic factors, such as nerve growth factor (NGF) [1], brain-derived neurotrophic factor (BDNF) [2], neurotrophin 3 (NT-3) [3], and glia-derived neurotrophic factor (GDNF) [4], are necessary for the functional maintenance and organization of neurons. Among various neurotrophic factors, NGF has been extensively investigated and found to show pleiotrophic effects, such as the induction of neuronal differentiation, neural cell survival, and prevention of apoptosis of neurons, in both central and peripheral nervous systems [1]. In rat pheochromocytoma (PC-12) cells, which have been used as an in vitro model system to study the mechanisms of neuronal differentiation, NGF induces their differentiation, leading to the extension of neurites and the development of the characteristics of sympathetic neurons [5]. In the course of our search for new neurotrophic substances from natural resources [6, 7], we succeeded in isolating two neurotrophic substances and identified them to be parguerol (1) [8] and isoparguerol (2) [8]. Here we report the isolation, identification, and neurotrophic activities of the two neurotrophic substances, $\mathbf{1}$ and $\mathbf{2}$, together with inactive 
deoxyparguerol acetate (3) [8].

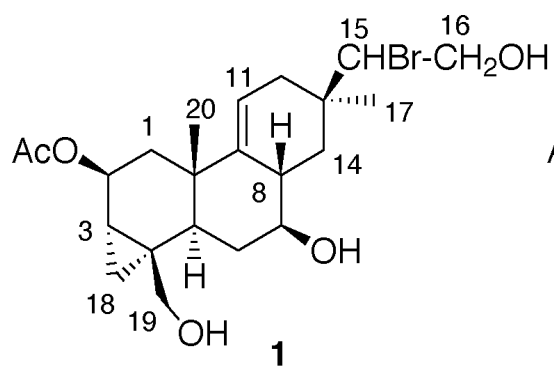

1

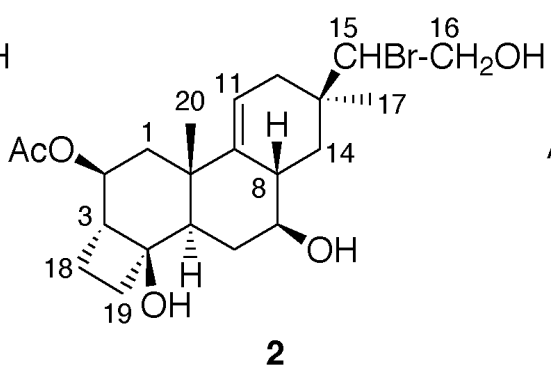

2

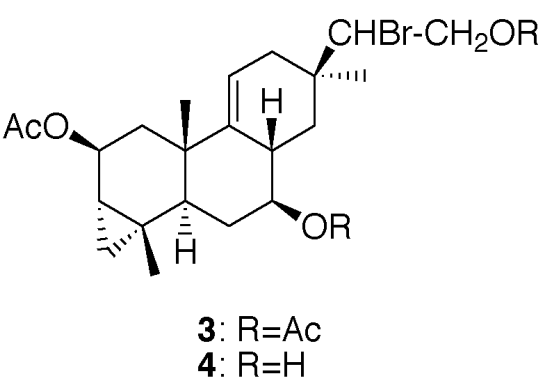

\section{Results and Discussion}

Specimens of Aplysia kurodai $(1.7 \mathrm{~kg}$ ) were collected by hand from Toyama Bay in the Japan Sea and kept frozen until extraction with $\mathrm{MeOH}$. After evaporation of the solvent, the resulting aqueous residue was extracted with EtOAc. The EtOAc layer showed neurotrophic activity in PC-12 cells and was fractionated by a combination of silica gel chromatography and gel permeation on Sephadex LH-20 to afford parguerol (1), isoparguerol (2), and deoxyparguerol acetate (3) in yields of $6.5 \times 10^{-5}, 4.1 \times 10^{-5}$, and $3.5 \times 10^{-5} \%$, respectively.

The FABMS of 1 showed 1:1 doublet ion peaks at $\mathrm{m} / \mathrm{z} 479$ and $481[\mathrm{M}+\mathrm{Na}]^{+}$, indicating the presence of a bromine atom in the molecule. The ${ }^{1} \mathrm{H}$ NMR spectrum of $\mathbf{1}$ measured in $\mathrm{CDCl}_{3}$ revealed two characteristic highfield signals assignable to a trisubstituted cyclopropane ring at $\delta$ 0.08 (t, $J=5.4 \mathrm{~Hz}$ ) and 0.88 (d, $J=10.2$ and $5.4 \mathrm{~Hz}$ ), two singlet methyls at $\delta 1.07$ (s) and 1.14 (s), one acetate methyl at $\delta 2.07$ (s), two pairs of hydroxymethyls at $\delta 3.84$ (dd, $J=12.7,9.3 \mathrm{~Hz}$ )/3.95 (dd, $J=12.7,2.9 \mathrm{~Hz}$ ) and $3.39(\mathrm{~d}, J=11.7 \mathrm{~Hz}) / 3.55(\mathrm{~d}, J=11.7 \mathrm{~Hz})$, three downfield methines at $\delta$ 3.18 (dt, $J=4.9$ and $11.7 \mathrm{~Hz}$ ), 4.28 (dd, $J=9.3$ and $2.9 \mathrm{~Hz}$ ), and 5.36 (d, $J=4.9 \mathrm{~Hz}$ ), and one trisubstituted double bond at $\delta 5.36(\mathrm{~d}, J=4.9 \mathrm{~Hz})$. These data were reminiscent of parguerol [8] which had been isolated from the sea hare, Aplysia dactylomela, collected in Puerto Rico, and finally analysis of 2D NMR data confirmed 1 to be parguerol.

Compound 2 showed the same ion peaks at $\mathrm{m} / \mathrm{z} 479$ and 481 (intensity, 1:1) $[\mathrm{M}+\mathrm{Na}]^{+}$as those of $\mathbf{1}$ in the FABMS. The ${ }^{1} \mathrm{H}$ NMR spectrum of $\mathbf{2}$ was similar to that of $\mathbf{1}$, except for the upfield shift of $\mathrm{H}-2$ at $\delta 4.96(\mathrm{~d}, J=4.0 \mathrm{~Hz}$ ) by $0.40 \mathrm{ppm}$ and the absence of the cyclopropane ring and a hydroxymethyl at C-19 in 2. The comparison of the ${ }^{1} \mathrm{H}$ NMR data of 2 and isoparguerol [8] in $\mathrm{CDCl}_{3}$ identified 2 as isoparguerol.

The ${ }^{1} \mathrm{H}$ NMR spectrum of $\mathbf{3}$ was also similar to that of $\mathbf{1}$, except for the presence of two more acetoxy methyls and the downfield shift of $\mathrm{H}-7$ at $\delta 4.40$ (dt, $J=4.9,11.7 \mathrm{~Hz}$ ) and $\mathrm{H}_{2}-16$ at $\delta 4.28$ $(2 \mathrm{H}, \mathrm{d}, J=9.8 \mathrm{~Hz}$ ) in 3, which implied the hydroxy groups at C-7 and C-16 in 1 were acetylated in 3. In addition, the spectrum suggested that the hydroxymethyl ( $\delta 3.55$ and 3.39) at C-19 in 1 was replaced with methyl $(\delta$ 1.02) in 3 . The presence of pseudomolecular ion peaks at $\mathrm{m} / \mathrm{z} 547 / 549$ 
(intensity, 1:1) $[\mathrm{M}+\mathrm{Na}]^{+}$in the FABMS supported identification of $\mathbf{3}$ as deoxyparguerol acetate. Although 3 was derived from deoxyparguerol (4) [8], this is the first isolation of $\mathbf{3}$ from natural resources.

Parguerol (1) and isoparguerol (2) showed significant neurotrophic effects on PC-12 cells (Fig. 1): More than $70 \%$ of the cells exhibited neurite outgrowth by treatments with $\mathbf{1}$ and $\mathbf{2}$ at concentrations of 25 and $50 \mu \mathrm{g} / \mathrm{mL}$, respectively, for 2 days. On the other hand, deoxyparguerol acetate (3) was unable to induce neurite extension even at a concentration of $100 \mu \mathrm{g} / \mathrm{mL}$, although it possesses the same skeleton as that of $\mathbf{1}$ and $\mathbf{2}$. It should be noted that both $\mathbf{1}$ and $\mathbf{2}$ induce bipolar (two-neurite-bearing) morphology, while NGF (a positive control) induces multipolar (multiple-neurite-bearing) morphology. The relationship between the morphological change and the cellular event has been extensively studied and elucidated in the case of murine neuroblastoma Neuro 2A cells [9]. However, such relationship remains obscure in the case of PC-12 cells. Further pharmacological study is needed to understand the mechanism of 1- and 2-induced morphological changes in PC-12 cells.

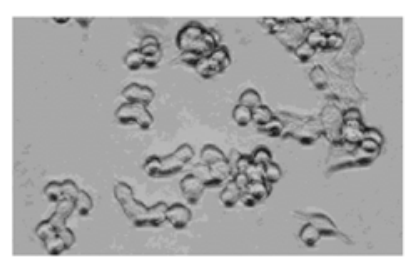

control

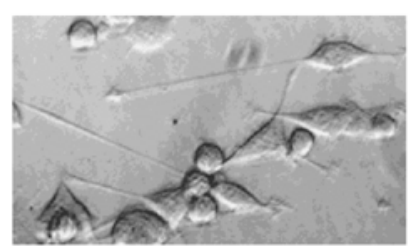

1

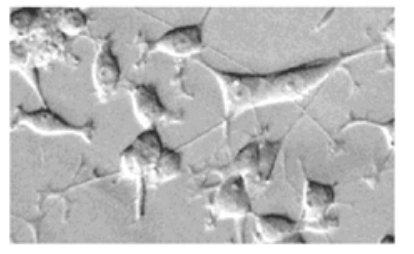

NGF

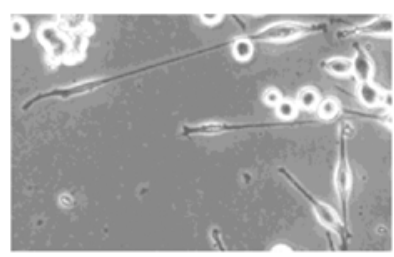

2

Fig. 1. Effects of 1, 2, and NGF on neurite outgrowth in PC-12 cells. PC-12 cells were incubated for 2 days in the absence (control) or presence of NGF (positive control) at $50 \mathrm{ng} / \mathrm{mL}, 1$ at $25 \mu \mathrm{g} / \mathrm{mL}$, or 2 at $50 \mu \mathrm{g} / \mathrm{mL}$.

It is well known that the content of sea hare digestive glands is dependent on diet that this animal ingests [10-13]. A large number of cognate metabolites have been isolated from both the red alga of the genus Laurencia and the sea hare that preys on the red alga. Metabolites isolated from sea hares exhibit various biological activities, for example, cytotoxic [14, 15], algicidal [15], antifungal [15, 16], and ichthyotoxic [16] activities: It can be inferred that sea hares contain such metabolites for the sake of their self-defense. This is the first report of sea hare metabolites that show neurotrophic activity. 


\section{Conclusions}

We have isolated parguerol (1), isoparguerol (2), and deoxyparguerol acetate (3) from the sea hare, Aplysia kurdai. In rat pheochromocytoma (PC-12) cells, 1 and $\mathbf{2}$ showed significant neurotrophic activities at concentrations of 25 and $50 \mu \mathrm{g} / \mathrm{mL}$, respectively, while 3 did not show such effect even at a concentration of $100 \mu \mathrm{g} / \mathrm{mL}$.

NGF activates neuronal function and prevents neuronal death in the brain. When peripherally administered, however, exogeneously administered NGF is thought to be unable to cross the blood-brain barrier. Therefore, low-molecular-weight NGF-like substances such as $\mathbf{1}$ or $\mathbf{2}$ are useful for treatment of various neuronal degenerative disorders.

\section{Experimental}

\section{General}

NMR spectra were recorded on a JEOL GSX500 in $\mathrm{CDCl}_{3}$. All chemical shifts were reported with respect to $\mathrm{CDCl}_{3}(\delta$ 7.26). Mass spectra were measured on a JEOL SX-102 mass spectrometer.

\section{Extraction and Isolation}

The frozen material (1.7 kg, wet wt) was extracted with $\mathrm{MeOH}$. The extract was concentrated under reduced pressure and extracted with EtOAc. The EtOAc layer (1.4 g) was subjected to silica gel chromatography with a stepwise gradient of hexane/EtOAc/MeOH. The most potent neurotrophic fraction (216.3 mg) eluted with EtOAc/MeOH (1:1) was purified by silica gel chromatography with $\mathrm{CHCl}_{3} / \mathrm{MeOH}$ (9:1) followed by gel permeation on Sephadex LH-20 to afford parguerol (1, $1.11 \mathrm{mg}, 6.5 \times 10^{-5} \%$ ), isoparguerol (2, $0.69 \mathrm{mg}, 4.1 \times 10^{-5} \%$ ), and deoxyparguerol acetate $\left(3,0.60 \mathrm{mg}, 3.5 \times 10^{-5} \%\right)$.

Parguerol (1): ${ }^{1} \mathrm{H}$ NMR $\left(\mathrm{CDCl}_{3}\right) \delta 0.08(1 \mathrm{H}, \mathrm{t}, J=5.4 \mathrm{~Hz}, \mathrm{H}-18 \mathrm{endo}), 0.88(1 \mathrm{H}, \mathrm{dd}, J=10.2,5.4$ Hz, H-18exo), 1.04 (1H, m, H-3), 1.07 (3H, s, H $3-17), 1.14$ (3H, s, H3-20), 1.14 (2H, m, H-1 and H-5), 1.49 (1H, m, H-14), 1.82 (1H, br d, $J=18.6 \mathrm{~Hz}, \mathrm{H}-12), 1.92$ (1H, t, $J=15.6 \mathrm{~Hz}, \mathrm{H}-1), 1.92$ (1H, m, H-6), 2.07 (3H, s, CH $\mathrm{CHOO}_{3}, 2.27$ (1H, m, H-8), 2.41 (1H, m, H-6), 2.42 (1H, m, H-12), $3.18(1 \mathrm{H}, \mathrm{dt}, J=4.9,11.7 \mathrm{~Hz}, \mathrm{H}-7), 3.39(1 \mathrm{H}, \mathrm{d}, J=11.7 \mathrm{~Hz}, \mathrm{H}-19), 3.55(1 \mathrm{H}, \mathrm{d}, J=11.7 \mathrm{~Hz}$, H-19), 3.84 (1H, dd, $J=12.7,9.3 \mathrm{~Hz}, \mathrm{H}-16), 3.95$ (1H, dd, $J=12.7,2.9 \mathrm{~Hz}, \mathrm{H}-16), 4.28$ (1H, dd, $J$ = 9.3, $2.9 \mathrm{~Hz}, \mathrm{H}-15)$, and $5.36(2 \mathrm{H}, \mathrm{d}, J=4.9 \mathrm{~Hz}, \mathrm{H}-2$ and $\mathrm{H}-11$ ). FABMS (positive, glycerol matrix) $\mathrm{m} / \mathrm{z}$ 479/481 (intensity, $1: 1)[\mathrm{M}+\mathrm{Na}]^{+}$.

Isoparguerol (2): ${ }^{1} \mathrm{H} \mathrm{NMR}\left(\mathrm{CDCl}_{3}\right) \delta 1.09$ (3H, s, $\left.\mathrm{H}_{3}-17\right), 1.22\left(3 \mathrm{H}, \mathrm{s}, \mathrm{H}_{3}-20\right), 1.44(1 \mathrm{H}, \mathrm{m}, \mathrm{H}-14)$, 1.67 (1H, dd, $J=15.1,4.9 \mathrm{~Hz}, \mathrm{H}-1), 1.76$ (1H, t, $J=15.1 \mathrm{~Hz}, \mathrm{H}-14), 1.86$ (1H, m, H-6), 1.86 (1H, m, H-12), 2.03 (3H, s, CH $\mathrm{CHOO}_{3} 2.10$ (1H, br d, $\left.J=15.1 \mathrm{~Hz}, \mathrm{H}-1\right), 2.28$ (1H, m, H-8), 2.45 (1H, br 
d, $J=18.6 \mathrm{~Hz}, \mathrm{H}-12), 2.53$ (1H, t, $J=14.7 \mathrm{~Hz}, \mathrm{H}-6), 3.28$ (1H, dt, $J=4.9,11.7 \mathrm{~Hz}, \mathrm{H}-7), 3.85$ (1H, dd, $J=12.7,9.8 \mathrm{~Hz}, \mathrm{H}-16), 3.92$ (1H, dd, $J=12.7,2.9 \mathrm{~Hz}, \mathrm{H}-16), 4.29$ (1H, dd, $J=9.8,2.9 \mathrm{~Hz}$, H-15), $4.96(1 \mathrm{H}, \mathrm{d}, J=4.0 \mathrm{~Hz}, \mathrm{H}-2)$, and $5.45(1 \mathrm{H}, \mathrm{d}, J=6.3 \mathrm{~Hz}, \mathrm{H}-11)$. FABMS (positive, glycerol matrix) $m / z$ 479/481 (intensity, $1: 1$ ) $[\mathrm{M}+\mathrm{Na}]^{+}$.

Deoxyparguerol acetate (3): ${ }^{1} \mathrm{H} \mathrm{NMR}\left(\mathrm{CDCl}_{3}\right) \delta 0.01(1 \mathrm{H}, \mathrm{m}, \mathrm{H}-18 \mathrm{endo}), 0.68(1 \mathrm{H}, \mathrm{m}, \mathrm{H}-18 \mathrm{exo})$, 1.02 (3H, s, $\left.\mathrm{H}_{3}-19\right), 1.05$ (3H, s, $\left.\mathrm{H}_{3}-17\right), 1.16$ (3H, s, $\left.\mathrm{H}_{3}-20\right), 1.90$ (1H, br d, $J=15.8 \mathrm{~Hz}, \mathrm{H}-1$ ), 2.07 (3H, $\mathrm{CH}_{3} \mathrm{COO}$ ), 2.09 (3H, $\mathrm{CH}_{3} \mathrm{COO}$ ), 2.13 (3H, $\mathrm{CH}_{3} \mathrm{COO}$ ), 2.42 (1H, br d, $J=18.6 \mathrm{~Hz}, \mathrm{H}-12$ ), 4.28 (2H, d, $\left.J=9.8 \mathrm{~Hz}, \mathrm{H}_{2}-16\right), 4.40$ (1H, dt, $\left.J=4.9,11.7 \mathrm{~Hz}, \mathrm{H}-7\right), 4.52$ (1H, dd, $\left.J=9.8,2.9 \mathrm{~Hz}, \mathrm{H}-15\right)$, 5.31 (1H, br d, $J=5.0 \mathrm{~Hz}, \mathrm{H}-2)$, and 5.39 (1H, br d, $J=6.5 \mathrm{~Hz}, \mathrm{H}-11$ ). FABMS (positive, glycerol matrix) $\mathrm{m} / \mathrm{z} 547 / 549$ (intensity, $1: 1)[\mathrm{M}+\mathrm{Na}]^{+}$.

\section{Neurite Outgrowth Assay}

Neurite outgrowth assay was carried out using rat pheochromocytoma (PC-12) cells. ${ }^{5}$ PC-12 cells were grown in Dulbecco's modified Eagle’s medium supplemented with 10\% fetal calf serum, 5\% horse serum, penicillin (50 units/mL), and streptomycin $(50 \mu \mathrm{g} / \mathrm{mL})$ in an incubator under $5 \% \mathrm{CO}_{2}$ at $37^{\circ} \mathrm{C}$. PC-12 cells were seeded onto 24 -well plates $\left(1 \times 10^{5}\right.$ cells $\left./ \mathrm{mL}\right)$ and cultivated for a day. The medium was replaced with that containing 1-3 or $5 \mathrm{ng} / \mathrm{mL}$ NGF (a positive control), and PC-12 cells were further cultivated for 2 days and observed under a phase-contrast microscope. The percentage of the cells with neurites was determined by counting 300 cells.

\section{Acknowledgments}

This work was supported by Grants-in-Aid for Scientific Research from the Ministry of Education, Science, Sports, Culture, and Technology of Japan.

\section{References and Notes}

1. Levi-Montalcini, R. The Nerve Growth Factor 35 Years Later. Science 1987, 237, 1154-1162.

2. Barde, Y. A.; Edgar, D.; Thoenen, H. Purification of a New Neurotrophic Factor from Mammalian Brain. EMBO J. 1982, 1, 549-553.

3. Maisonpierre, P. C.; Belluscio, L.; Squinto, S.; Ip, N. Y.; Furth, M. E.; Lindsay, R. M.; Yancopoulos, G. D. Neurotrophin-3: a Neurotrophic Factor Related to NGF and BDNF. Science 1990, 247, 1446-1451.

4. Lin, L.-F. H.; Doherty, D. H.; Lile, J. D.; Bektesh, S., Collins, F. GDNF: A Glial Cell Line-Derived Neurotrophic Factor for Midbrain Dopaminergic Neurons. Science 1993, 260, 1130-1132. 
5. Greene, L. A.; Tischler, A. S. Establishment of a Noradrenergic Clonal Line of Rat Adrenal Pheochromocytoma Cells Which Respond to Nerve Growth Factor. Proc. Natl. Acad. Sci. USA 1976, 73, 2424-2428.

6. Tsukamoto, S.; Macabalang, A. D.; Nakatani, K.; Obara, Y.; Nakahata, N.; Ohta, T. Tricholomalides A-C: New Neutrophic Diterpenes from the Mushroom Tricholoma sp. J. Nat. Prod. 2003, 66, 1578-1581.

7. Tsukamoto, S.; Miura, S.; Yamashita, Y.; Ohta, T. Aspermytin A: a New Neurotrophic Polyketide Isolated from a Marine-derived Fungus of the Genus Aspergillus. Bioorg. Med. Chem. Lett. 2004, 14, 417-420.

8. Schmitz, F. J.; Michaud, D. P.; Schmidt, P. G. Marine Natural Products: Parguerol, Deoxyparguerol, and Isoparguerol. New Brominated Diterpenes with Modified Pimarane Skeletons from the Sea Hare Aplysia dactylomela. J. Am. Chem. Soc. 1982, 104, 6415-6423.

9. Fenteany, G.; Schreiber, S. L. Specific Inhibition of the Chymotrypsin-like Activity of the Proteasome Induces a Bipolar Morphology in Neuroblastoma Cells. Chem. Biol. 1996, 3, 905-912.

10. Erickson, K. L. Constituents of Laurencia. In Marine Natural Products; Scheuer, P. J., Ed.; Academic: New York, 1983; Vol. V, p 132.

11. Stallard, M. O.; Faulkner, D. J. Chemical Constituents of the Digestive Gland of the Sea Hare Aplysia californica. I. Importance of Diet. Comp. Biochem. Physiol. B 1974, 49B, 25-35.

12. Stallard, M. O.; Faulkner, D. J. Chemical Constituents of the Digestive Gland of the Sea Hare Aplysia californica. II. Chemical Transformations. Comp. Biochem. Physiol. B 1974, 49B, 37-41.

13. Ireland, C.; Stallard, M. O.; Faulkner, D. J. Some Chemical Constituents of the Digestive Gland of the Sea Hare Aplysia californica. J. Org. Chem. 1976, 41, 2461-2465.

14. Yamada, K.; Ojika, M.; Ishigaki, T.; Yoshida, Y.; Ekimoto, H.; Arakawa, M. Aplyronine A, a Potent Antitumor Substance, and the Congeners Aplyronines B and C Isolated from the Sea Hare Aplysia kurodai. J. Am. Chem. Soc. 1993, 115, 11020-11021.

15. Wessels, M.; Konig, G. M.; Wright, A. D. New Natural Product Isolation and Comparison of the Secondary Metabolite Content of Three Distinct Samples of the Sea Hare Aplysia dactylomela from Tenefife. J. Nat. Prod. 2000, 63, 920-928.

16. Ichiba, T.; Higa, T. New Cuparene-derived Sesquiterpenes with Unprecedented Oxygenation Patterns from the Sea Hare Aplysia dactylomela. J. Org. Chem. 1986, 51, 3364-3366.

Samples Availability: Not available.

(c) 2004 by MDPI (http://www.mdpi.org). Reproduction is permitted for noncommercial purposes. 